\title{
The Effect of Moisture Content of Black Locust Wood on the Heating in the Saturated Water Steam during the Process of Colour Modification
}

\author{
Ladislav Dzurenda ${ }^{1, *}$ \\ ${ }^{1}$ Department of Wood Working, Technical University in Zvolen, Zvolen, Slovak Republic
}

\begin{abstract}
The effect of moisture content of black locust wood on the heating of sawn timber with the thickness of $h=32 \mathrm{~mm}$ in saturated water steam during the processes of colour modifications by modes: mode I temperature of saturated water steam $t=112 \pm 2.5{ }^{\circ} \mathrm{C}$ for $\tau=5.5$ hours, mode II - temperature of saturated water steam $\mathrm{t}=127 \pm 2.5^{\circ} \mathrm{C}$ for $\tau=6.5$ hours, and mode III - temperature of saturated water steam $\mathrm{t}=137 \pm 2.5^{\circ} \mathrm{C}$ for $\tau=7.5$ hours is analysed in the paper. The increase in moisture content affects the heating time, it lasts longer. When the moisture content of black locust wood ranges from $\mathrm{W}=60-65 \%$, the heating time by modes I - III did not last longer than the time $\Delta \tau \leq 0.5 \mathrm{~min}$. and no negative impact on the final colour modification is observed.
\end{abstract}

\section{Introduction}

Wood placed in the environment of hot water, saturated water steam or saturated humid air is getting warmer and its physical, mechanical and chemical properties changes. Mentioned facts come in useful in the technology of wood steaming and boiling used in the producing veneers and plywood, bent furniture or pressed wood. Processes of wood heat treatment in saturated water steam result not only in changes of physical, mechanical and chemical wood properties but also in changes of colour. In the past, colour modification, especially wood darkening, was used to remove undesirable differences in colour of lighter sapwood and darker heartwood, or to remove wood stains resulting from steaming or moulding. Recently, the issue of colour modification of various wood species has become of great importance [1-6].

Firstly, the wood is heated to the required temperature in the shortest time. Initial moisture content of modified wood must be taken into account during manufacturing processes. Various moisture contents of analysed wood species can affect physical properties of wood, such as density, heat capacity, thermal conductivity. Process and the length of non-stationary temperature distribution during heating are affected by mentioned physical properties directly.

\footnotetext{
*Corresponding author: dzurenda@tuzvo.sk
} 
The aim of the paper is to analyse the effect of initial moisture content of black locust wood ranged from $\mathrm{w}=40-100 \%$ on the heating time of sawn timber with the thickness of $\mathrm{h}=32 \mathrm{~mm}$ in saturated water steam during the processes of colour modification by modes: mode $\mathrm{I}$ - temperature of saturated water steam $\mathrm{t}=112 \pm 2.5^{\circ} \mathrm{C}$ for $\tau=5.5$ hours, mode II temperature of saturated water steam $\mathrm{t}=127 \pm 2.5^{\circ} \mathrm{C}$, for $\tau=6.5$ hours, and mode III temperature of saturated water steam $\mathrm{t}=137 \pm 2.5^{\circ} \mathrm{C}$ for $\tau=7.5$ hours.

\section{Model to Calculate the Heating Time of Sawn Timber in Saturated Water Steam}

Sawn timber heating by saturated water steam in an autoclave is described by Fourier's equation of heat conduction, one-dimensional, steady-state conduction, i.e. amount of heat transmitted under the given temperature and boundary conditions.

$$
\Theta=\frac{\mathrm{t}_{x}-\mathrm{t}_{p}}{\mathrm{t}_{0}-\mathrm{t}_{p}}=\sum_{i=1}^{\infty} \frac{2 \cdot(-1)^{i+1}}{\beta_{i}} \cos \left(\beta_{i} \frac{\mathrm{x}}{\mathrm{b}}\right) \cdot \mathrm{e}^{-\beta_{i}^{2} \cdot F o}
$$

Lykov [7] published a nomogram of the relation $\boldsymbol{\theta}=\boldsymbol{f}(\boldsymbol{x} / \boldsymbol{b}, \boldsymbol{F o})$ to determine dimensionless heat $\theta$ of the infinite long and wide sawn timber $b<<y<<z$ for wood heating at the high value of heat transfer coefficient $\alpha \rightarrow \infty$. Heating of both surfaces $x / b=1$ is as follows:

$$
F_{o}=-0.419 \cdot \ln (\theta)+0.0769
$$

Time necessary for heating the sawn timber can be defined following the Fourier number by the equation:

$$
\tau=\frac{\text { Fo.b }}{\mathrm{a}}
$$

Fo is Fourier number, $\mathrm{b}$ is $1 / 2$ of the thickness of a board, $\mathrm{a}$ is a heat transfer coefficient.

\subsection{Technological Parameters of Wood Heating by Saturated Water Steam}

Heating time of black locust wood with the thickness of $\mathrm{h}=32 \mathrm{~mm}$ in saturated water steam by individual modes of colour modification process is analysed for initial values of moisture content ranged: $\mathrm{W}=40 \div 100 \%$. Physical properties of heated black locust wood: wood density $\rho_{\mathrm{w}}$, specific wood heat capacity $\mathrm{c}_{\mathrm{w}}$, heat transfer coefficient perpendicular to the fibres in tangential direction $\lambda_{\mathrm{w} \perp}$ and thermal conductivity of wood $\mathrm{a}_{\mathrm{w}}$ for individual moisture content $\mathrm{W}$ and the temperature calculated $\mathrm{t}_{\mathrm{vyp}}$ are shown in Table 1. Temperature calculated in the process of non-stationary temperature distribution during heating by individual modes of colour modification are determined using the equation:

$$
\mathrm{t}_{v y p}=\frac{\mathrm{t}_{0}+\left(\mathrm{t}_{x}+\mathrm{t}_{\mathrm{p}}\right) / 2}{2}
$$

$t_{0}$ is a temperature of sawn timber at the beginning of heating, $t_{\mathrm{x}}$ temperature of heated sawn timber in the $1 / 2$ of thickness, $t_{\mathrm{p}}$ is a temperature on the sawn timber surface.

Temperature in the centre of the sawn timber thickness $t_{x}$ is lower $\Delta t=2.5^{\circ} \mathrm{C}$ in comparison to the temperature on the sawn timber surface.

$$
t_{x}=t_{p}-2.5
$$


$t_{\mathrm{p}}$ is a temperature of the sawn timber surface.

Table 1. Parametres of physical values of black locust [8-12].

\begin{tabular}{|c|c|c|c|c|c|c|}
\hline \multirow{2}{*}{$\begin{array}{l}\text { Temperature } \\
\text { calculated } t_{\mathrm{vyp}}\end{array}$} & Parameter & $40 \%$ & $50 \%$ & $60 \%$ & $80 \%$ & $100 \%$ \\
\hline & $\rho_{\mathrm{w}}\left[\mathrm{kg} \cdot \mathrm{m}^{-3}\right]$ & 875 & 937 & 1.000 & 1.125 & 1.250 \\
\hline \multirow{3}{*}{$\begin{array}{c}\text { mode I } \\
t_{\text {vyp }}=60^{\circ} \mathrm{C}\end{array}$} & $\mathrm{c}_{\mathrm{w}}\left[\mathrm{J} \cdot \mathrm{kg}^{-1} \cdot \mathrm{K}^{-1}\right]$ & 2.738 & 2.869 & 2.984 & 3.175 & 3.328 \\
\hline & $\lambda_{\mathrm{w} \perp}\left[\mathrm{W} \cdot \mathrm{m}^{-1} \cdot \mathrm{K}^{-1}\right]$ & 0.452 & 0.491 & 0.532 & 0.611 & 0.685 \\
\hline & $\mathrm{a}_{\mathrm{w}}\left[\mathrm{m}^{2} \cdot \mathrm{s}^{-1}\right]$ & $0.188 \cdot 10^{-6}$ & $0.182 \cdot 10^{-6}$ & $0.178 \cdot 10^{-6}$ & $0.171 \cdot 10^{-6}$ & $0.163 \cdot 10^{-6}$ \\
\hline \multirow{3}{*}{$\begin{array}{c}\text { mode II } \\
t_{\text {vyp }}=68^{\circ} \mathrm{C}\end{array}$} & $\mathrm{c}_{\mathrm{w}}\left[\mathrm{J} \cdot \mathrm{kg}^{-1} \cdot \mathrm{K}^{-1}\right]$ & 2.770 & 2.901 & 3.016 & 3.207 & 3.360 \\
\hline & $\lambda_{\mathrm{w} \perp}\left[\mathrm{W} \cdot \mathrm{m}^{-1} \cdot \mathrm{K}^{-1}\right]$ & 0.467 & 0.508 & 0.549 & 0.631 & 0.705 \\
\hline & $a_{w}\left[m^{2} \cdot s^{-1}\right]$ & $0.192 \cdot 10^{-6}$ & $0.186 \cdot 10^{-6}$ & $0.182 \cdot 10^{-6}$ & $0.174 \cdot 10^{-6}$ & $0.168 \cdot 10^{-6}$ \\
\hline \multirow{3}{*}{$\begin{array}{c}\text { mode III } \\
\mathrm{t}_{\mathrm{vyp}}=73^{\circ} \mathrm{C}\end{array}$} & $\mathrm{c}_{\mathrm{w}}\left[\mathrm{J} \cdot \mathrm{kg}^{-1} \cdot \mathrm{K}^{-1}\right]$ & 2.797 & 2.928 & 3,043 & 3.235 & 3.388 \\
\hline & $\lambda_{\mathrm{w} \perp}\left[\mathrm{W} \cdot \mathrm{m}^{-1} \cdot \mathrm{K}^{-1}\right]$ & 0.473 & 0.515 & 0.557 & 0.641 & 0.725 \\
\hline & $a_{w}\left[m^{2} \cdot s^{-1}\right]$ & $0.193 \cdot 10^{-6}$ & $0.187 \cdot 10^{-6}$ & $0.183 \cdot 10^{-6}$ & $0.176 \cdot 10^{-6}$ & $0.171 \cdot 10^{-6}$ \\
\hline
\end{tabular}

Wood temperatures during the heat treatment process by individual modes of colour modification of black locust wood are shown in Table 2 .

Table 2. Temperatures of sawn timber during the process of heat treatment.

\begin{tabular}{|c|c|c|c|}
\hline \multirow{2}{*}{ Mode } & \multicolumn{3}{|c|}{ Temperature of sawn timber } \\
\cline { 3 - 4 } & $\mathrm{t}_{\mathrm{o}}$ & $\mathrm{t}_{\mathrm{p}}$ & $\mathrm{t}_{\mathrm{x}}$ \\
\hline $\mathrm{I}$ & \multirow{3}{*}{$10{ }^{\circ} \mathrm{C}$} & $\mathrm{t}_{\mathrm{p}}=112.5^{\circ} \mathrm{C}$ & $\mathrm{t}_{\mathrm{x}}=110^{\circ} \mathrm{C}$ \\
\cline { 3 - 4 } & $\mathrm{t}_{\mathrm{p}}=127.5^{\circ} \mathrm{C}$ & $\mathrm{t}_{\mathrm{x}}=125^{\circ} \mathrm{C}$ \\
\cline { 3 - 4 } & & $\mathrm{t}_{\mathrm{p}}=137.5^{\circ} \mathrm{C}$ & $\mathrm{t}_{\mathrm{x}}=135^{\circ} \mathrm{C}$ \\
\hline III
\end{tabular}

\section{Result and discussion}

Time of non-stationary temperature distribution during heating of black locust sawn timber with the thickness of $\mathrm{h}=32 \mathrm{~mm}$ in saturated water steam by individual modes of colour modification is illustrated in Figure 1.

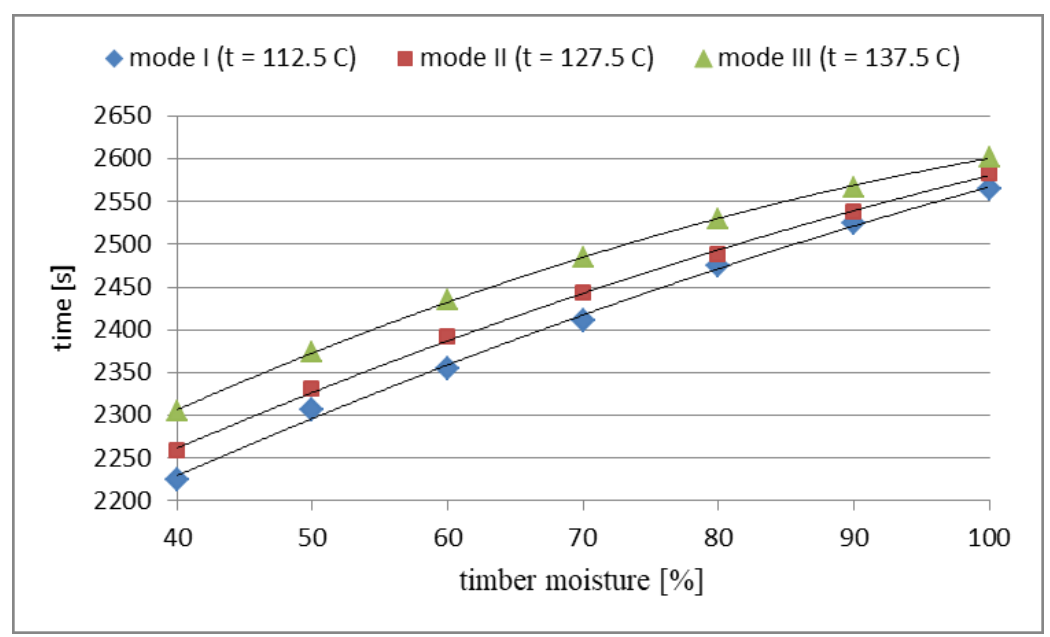

Fig. 1. Heating time of black locust sawn timber depending upon the moisture content of wood and mode of colour modification. 
Dependences of heating time of black locust sawn timber with the thickness of $h=32$ $\mathrm{mm}$ on the moisture content of wood $\mathrm{W}=40-100 \%$ to the required temperature in individual modes of colour modification are shown in Table 3.

Table 3. Dependences of heating time of black locust sawn timber on the temperature of the saturated water steam.

\begin{tabular}{|c|c|c|}
\hline $\begin{array}{c}\text { Temperature of } \\
\text { saturated water steam }\end{array}$ & Functional dependence & $\begin{array}{c}\text { Coefficient of } \\
\text { determination }\end{array}$ \\
\hline $\mathrm{t}^{\prime \prime}=112.5^{\circ} \mathrm{C}$ & $\tau=-0.0214 \cdot \mathrm{w}^{2}+8.6286 \cdot \mathrm{w}+1,918.4$ & $\mathrm{R}^{2}=0.9974$ \\
\hline $\mathrm{t}^{\prime \prime}=127.5^{\circ} \mathrm{C}$ & $\tau=-0.0243 \cdot \mathrm{w}^{2}+8.7143 \cdot \mathrm{w}+1,951.7$ & $\mathrm{R}^{2}=0.9990$ \\
\hline $\mathrm{t}^{\prime \prime}=137.5^{\circ} \mathrm{C}$ & $\tau=-0.0350 \cdot \mathrm{w}^{2}+9.8000 \cdot \mathrm{w}+1,970.4$ & $\mathrm{R}^{2}=0.9998$ \\
\hline
\end{tabular}

The increase in the moisture content of black locust wood affect the heating time of sawn timber to the required temperature, it prolongs. The change in mode I is from $\tau_{\mathrm{w}=40 \%}=$ $37.08 \mathrm{~min}$ to $\tau_{\mathrm{w}=100 \%}=42.75 \mathrm{~min}$, it means the heating time is $\Delta \tau=5.67 \mathrm{~min}$ longer.

The average moisture content of modified sawn timber in operating conditions is $60 \%$ and moisture content variation is $\Delta \mathrm{W}= \pm 5 \%$. Table 4 shows the values of prolonged heating associated with the moisture content variation $\Delta \mathrm{W}= \pm 5 \%$, as well as extreme values $\Delta \mathrm{W}= \pm 10 \%$ for individual modes of colour modification of black locust sawn timber with the moisture content $\mathrm{W}=60 \%$ and the thickness of $\mathrm{h}=32 \mathrm{~mm}$.

Table 4. Effect of increased moisture content of black locust wood on the prolonged heating to the required temperature.

\begin{tabular}{|c|c|c|c|c|c|}
\hline \multirow{3}{*}{$\begin{array}{l}\text { Mode } \\
\text { Mode } \\
\text { I }\end{array}$} & \multirow{3}{*}{$\begin{array}{c}\begin{array}{c}\text { Heating time of } \\
\text { sawn timber } \mathbf{h} \\
=\mathbf{3 2} \mathbf{~ m m} \text { thick, } \\
\mathbf{w}=\mathbf{6 0} \%\end{array} \\
\tau=39.25 \mathrm{~min}\end{array}$} & \multicolumn{2}{|c|}{$\begin{array}{c}\text { Prolongation of heating time of } \\
\text { sawn timber because of higher } \\
\text { moisture content } \Delta W=+5 \% \text { and } \\
\Delta W=+10 \%\end{array}$} & \multicolumn{2}{|c|}{$\begin{array}{c}\begin{array}{c}\text { Relative prolongation of heating } \\
\text { time of sawn timber }\end{array} \\
\qquad \tau=\frac{\tau_{60 \%}-\tau_{60 \%+\Delta W}}{\tau_{60 \%}} \cdot 100 \%\end{array}$} \\
\hline & & $\Delta W=+5 \%$ & $\Delta \tau=0.46 \mathrm{~min}$ & $\Delta \mathrm{W}=+5 \%$ & $\Delta \tau=1.17 \%$ \\
\hline & & $\Delta \mathrm{W}=+10 \%$ & $\Delta \tau=0.91 \mathrm{~min}$ & $\Delta \mathrm{W}=+10 \%$ & $\Delta \tau=2.28 \%$ \\
\hline \multirow{2}{*}{$\begin{array}{c}\text { Mode } \\
\text { II }\end{array}$} & \multirow{2}{*}{$\tau=39.85 \mathrm{~min}$} & $\Delta \mathrm{W}=+5 \%$ & $\Delta \tau=0.43 \mathrm{~min}$ & $\Delta \mathrm{W}=+5 \%$ & $\Delta \tau=1.08 \%$ \\
\hline & & $\Delta \mathrm{W}=+10 \%$ & $\Delta \tau=0.87 \mathrm{~min}$ & $\Delta \mathrm{W}=+10 \%$ & $\Delta \tau=2.12 \%$ \\
\hline \multirow{2}{*}{$\begin{array}{c}\text { Mode } \\
\text { III }\end{array}$} & \multirow{2}{*}{$\tau=40.57 \mathrm{~min}$} & $\Delta \mathrm{W}=+5 \%$ & $\Delta \tau=0.42 \mathrm{~min}$ & $\Delta \mathrm{W}=+5 \%$ & $\Delta \tau=1.03 \%$ \\
\hline & & $\Delta \mathrm{W}=+10 \%$ & $\Delta \tau=0.85 \mathrm{~min}$ & $\Delta \mathrm{W}=+10 \%$ & $\Delta \tau=2.04 \%$ \\
\hline
\end{tabular}

Due to the increase in the moisture content of black locust wood, the heating time of sawn timber to the required temperature is longer. Mentioned prolongation of heating time depending upon the temperature of saturated water steam by the mode of colour modification at the standard moisture content variation $\Delta \mathrm{W}= \pm 5 \%$ is no longer than $\Delta \tau \leq 0.5 \mathrm{~min}$. and does not affect the process in negative way. Mentioned findings are confirmed by determining the colour of black locust wood [13].

\section{Conclusion}

The findings of the analyses of the effect of moisture content of black locust wood on the time of non-stationary temperature distribution during heating by saturated water steam during the process of wood colour modification are presented in the paper. The increase in moisture content can cause the changes in physical properties of wood, such as wood density, specific heat capacity, heat transfer coefficient, thermal conductivity. Subsequently, the heating time of wood to required temperature is longer. The time of nonstationary temperature distribution during heating of black locust sawn timber with the thickness of $\mathrm{h}=32 \mathrm{~mm}$, with the moisture content $\mathrm{W}=60 \%$ in saturated water steam with the temperature of $\mathrm{t}^{\prime \prime}=112.5^{\circ} \mathrm{C}$ by mode $\mathrm{I}$ is $\tau=39.25 \mathrm{~min}$, in saturated water steam with 
the temperature of $\mathrm{t}^{\prime \prime}=127.5^{\circ} \mathrm{C}$ by mode II is $\tau=39.85 \mathrm{~min}$ and in saturated water steam with the temperature of $\mathrm{t}^{\prime \prime}=137.5^{\circ} \mathrm{C}$ by mode III is $\tau=40.57 \mathrm{~min}$. When the moisture content of black locust wood ranges from $\mathrm{W}=60-65 \%$ the heating time by any mode of colour modification did not prolong the time $\Delta \tau \leq 0.5 \mathrm{~min}$ and did not have a negative impact on colour modification.

This paper was prepared within the grant project: VEGA-SR No: $1 / 0563 / 16$, as the result of work of author and the considerable assistance of the VEGA-SR agency.

\section{References}

1. L. Tolvaj, R. Nemeth, D. Varga, S. Molnar, Drewno. 52 (181), 5-17, (2009)

2. I. Klement, P. Marko, Wood research 54 (3), 45-54, (2009)

3. L. Dzurenda, Acta Facultatis Xylologiae Zvolen, 56 (1), 13-22, (2014)

4. Š. Barcik, M. Gašparík, E.Y. Razumov, Wood Research. 60 (3), 385-396, (2015)

5. J. Barański, I. Klement, T. Vilkovská, A. Konopka, BioResources, 12 (1), (2017)

6. L. Dzurenda, BioResouces, 13 (1), (2018)

7. A.V. Lykov, Teplo i masoobmen v processach sushki. Moskva. Gosenergoizdat (1956)

8. B.S. Chudinov, Teorija teplovoj obrabotki drevesiny. Moskva. Nauka (1968)

9. N. Deliiski, Transient Heat Conduction in Capillary Porous Bodies, (InTech 2012)

10. K. Radmanović, I. Dukić, S. Pervan, Drvna industrija 65 (2), 151-157, (2014)

11. R. Hrčka, M. Babiak, Intech Europe, Rijeka, Croatia. (2017)

12. N. Deliiski, L. Dzurenda, D. Angelski, N. Tumbarkova, Acta Facultatis Xylologiae Zvolen. 60 (1), 101-112, (2018)

13. L. Dzurenda, Acta Facultatis Xylologiae Zvolen. 60 (1), 61-70, (2018) 